\title{
Os marginalizados e a ética de Leonilson ${ }^{1}$
}

\author{
Karoline Stoltz Schleder ${ }^{2}$ \\ Katiucya Perigo ${ }^{3}$
}

Resumo: Objetiva-se explorar, na obra do artista Leonilson(1957-1993), a questão da homossexualidade, investigando a forma como esse tema é desenvolvido e sua possível relação com o modo com que a homossexualidade é abordada pela sociedade atual. A evidência de homofobia e a crescente discussão em torno da temática da diversidade possibilitam ampliar significados sobre a obra desse artista. Nesta pesquisa qualitativa, realizou-se levantamento bibliográfico nos periódicos CAPES, arquivos de instituições locais e análise documental de sua obra. A presença recorrente da ambiguidade e o questionamento das verdades na obra de Leonilson apontam para a reflexão sobre a diversidade de gênero, para uma 'não questão da homossexualidade', como uma das formas de existência do humano. É nesse sentido também que Leonilson trata de outros grupos marginalizados. A reflexão sobre gênero a partir da obra de Leonilson merece ser mais explorada, tendo em vista a escassez de pesquisas sobre esse artista brasileiro.

Palavras-chave: Leonilson, homossexualidade, arte contemporânea.

Abstract: This paper intends to explore, through the works of the artist Leonilson (1957-1993), the question of homosexuality, investigating the way in which this theme is developed and its possible relationship with the manner in which homosexuality is approached by contemporary society. Evidence of homophobia and the growing discussion about the theme of diversity have enabled the work of this artist to take on greater significations. In this qualitative study a bibliographical search was performed in CAPES periodicals and the archives of local institutions, as well as document analysis of his works. The recurring presence of ambiguity and the questioning of truths in Leonilson's work point to a reflection on gender diversity, to a 'non-issue of homosexuality', as one of the forms of human existence. It is also in this sense that Leonilson deals with other marginalized groups. Reflection on gender based on the works of Leonilson deserves to be explored more, in view of the scarcity of research on this Brazilian artist.

Keywords: Leonilson, homosexuality, contemporary art.

${ }^{1}$ Pesquisa desenvolvida em programa de iniciação científica, CNPq.

${ }^{2}$ Graduada em Psicologia, pela Universidade Federal do Paraná, e graduanda em Pintura, pela Escola de Música e Belas Artes do Paraná - UNESPAR.

${ }^{3}$ Doutora em História, pela Universidade Federal do Paraná. Professora adjunta de História da Arte na Escola de Música e Belas Artes do Paraná - UNESPAR. 


\section{Introdução}

José Leonilson Bezerra Dias (1957-1993) é artista referência da arte contemporânea brasileira. Ele se destaca por sua originalidade. Leonilson tem um discurso intenso do sujeito e o caráter autobiográfico de sua obra indica a presença de uma narrativa de si (HERKENHOFF apud OLIVA, 1999; LAGNADO, 2000; RICCIOPPO, 2008). Além disso, o modo como Leonilson opera com as palavras o singulariza (DE ARAÚJO, 2011).

Arte e vida em Leonilson são intrínsecas (CINTRAO, 1997; CHAIMOVICH, 1998; PEDROSA in LAGNADO, 2000; GOIS, 2014). E assim, sua produção artística se configura de modo extremamente intimista, na qual sua vida privada é a estrutura para sua obra.

Leonilson viveu a maior parte de sua vida em São Paulo. Ele teve uma educação marcadamente religiosa e sua formação artística foi composta pelo curso inconcluso de Licenciatura em Educação Artística, viagens ao exterior e participação nas aulas da Escola de Artes Aster. Em 1984, fez parte da exposição "Como vai você, geração 80?" e, no ano seguinte, expos na XVIII Bienal Internacional de São Paulo. Em 1991, o artista descobriu ser soropositivo ao HIV e, em 1993, faleceu.

A produção de Leonilson refere-se principalmente a pinturas, desenhos e bordados. No início de sua carreira, ele pintava grandes lonas sem o tradicional chassi. Com o passar dos anos, especialmente em seus últimos anos de vida, adoecido, seus trabalhos se tornaram cada vez mais sintéticos, sendo o uso da palavra bordada sobre tecido uma das características marcantes de sua obra. Embora seja prudente não 
compartimentalizar a obra, destacam-se três núcleos formativos que acompanham a obra do artista: "prazer da pintura" (1983-1988), "abandono" (1989-1991) e "alegoria da doença" (1992-1993) (LAGNADO, 2000). A autora também delineia questões abordadas na obra de Leonilson: "a necessidade de fixação de uma memória, o discurso amoroso entre eros e logos, as figuras do romantismo, a ambiguidade dos valores morais e religiosos, a amizade e a paixão, a alegoria da doença, os limites da pintura e o uso do corpo como suporte" (LAGNADO, 2000, p.15).

O presente estudo tem como objetivo explorar uma das questões presentes na obra de Leonilson, a homossexualidade, visando os seguintes aspectos: investigar a forma como esse tema é desenvolvido e analisar a possível relação com o modo com que a homossexualidade é abordada pela sociedade atual.

\section{Cristãos menos iluminados}

Este trabalho justifica-se não somente pela importância deste artista para a história da arte brasileira, mas também pela atualidade dos temas que aborda, o que possibilita compreender melhor sua obra e ampliar a compreensão sobre o debate atual. Leonilson era homossexual, viveu na década de 80 e apresenta obra de caráter autobiográfico. O modo como a temática da homossexualidade é explorada nas obras de Leonilson, se torna relevante para se pensar a atualidade, tendo em vista a evidência de homofobia e crescente discussão em torno da temática da diversidade. 
Da época de Leonilson para os dias atuais, observam-se avanços nos direitos da comunidade LGBT. Em 2011, a união estável entre pessoas do mesmo sexo foi reconhecida e, em 2013, os cartórios de todo o Brasil tornaram-se obrigados a realizar casamentos de pessoas do mesmo sexo (REVISTA VEJA, 2003). Entretanto, o preconceito em relação ao grupo LGBT não cessou.

Mott (2006) nos lembra que os direitos afetivos e sexuais são direitos humanos e que estes, por sua vez, são universais e alienáveis. Em contraste a esse ideal, tem-se o panorama da homofobia no Brasil:

Em Brasília, 88\% dos jovens entrevistados pela Unesco consideram normal humilhar gays e travestis, $27 \%$ não querem ter homossexuais como colegas de classe e 35\% dos pais e mães de alunos não gostariam que seus filhos tivessem homossexuais como colegas de classe. Mais grave ainda: no Brasil, um gay, travesti ou lésbica é barbaramente assassinado a cada dois dias, vítima da homofobia (MOTT, 2006, p. 511).

Em pesquisa sobre a regulação da sexualidade em perspectivas pastorais evangélicas, Natividade (2006) identifica três modelos de afirmação sobre a homossexualidade que são recorrentes nesse âmbito: a homossexualidade seria um comportamento aprendido, um problema espiritual ou uma antinatureza. Nesse sentido, o homossexual é compreendido como o "nem homem, nem mulher", em que o sexo e identidade de gênero são um conceito só. Segundo Natividade (2006), as terapias de cunho religioso identificadas em sua pesquisa, também apresentam teorias psicologizantes, nas quais a homossexualidade é compreendida como anormal, patológica. Faz-se bem lembrar que a 
bancada evangélica de políticos brasileiros mais uma vez cresce em número, o que, segundo Bacelar e Carvalho (2014), deve afetar a luta do movimento LGBT por seus direitos.

Cenas em que a bancada evangélica de deputados protesta contra a parada gay em plena votação na câmara (HAUBERT, 2015), ou em que a câmara de deputados realiza audiência para ouvir ex-homossexuais, de modo a contribuir no seu debate sobre a 'cura gay' (DIÓGENES, 2015), configuram uma realidade talvez não tão diferente quanto aquela em que Leonilson viveu. Nesse sentido, o presente estudo pode ampliar o espectro de compreensão sobre esse artista.

\section{Método}

Trata-se de uma pesquisa qualitativa, na qual foi realizado levantamento bibliográfico com o indexador Leonilson, sem refinamento, nos periódicos da Coordenação de Aperfeiçoamento de Pessoal de Nível Superior- CAPES e arquivos de instituições locais: bibliotecas do Museu de Arte Contemporânea do Paraná- MAC PR, Universidade Federal do Paraná- UFPR, UNESPAR (Faculdade de Artes do Paraná- Escola de Música e Belas Artes do Paraná) e Museu da Gravura- PR. Optou-se por tal base de dados, por contemplar vasta quantidade de periódicos científicos. Essas instituições locais foram selecionadas por conterem parte significativa da documentação na área de artes visuais da região de Curitiba- PR. Além disso, foi realizada busca sobre as obras do artista, que foi facilitada pela consulta ao site Projeto Leonilson, um local que fornece e organiza expressivo arquivo digital. 
Em segundo momento, realizou-se análise documental das obras do artista. Obras de Leonilson foram selecionadas de modo a pautar a análise sobre a temática da sexualidade em seu trabalho e sua possível contribuição para a reflexão sobre questões da atualidade.

A base metodológica desse estudo fundamenta-se em Jacques Revel (2010), historiador da micro-história. Esta abordagem possibilita refletir sobre a realidade a partir de trajetórias individuais, como é o caso do presente estudo. Pensa-se que a história da arte também pode se utilizar de acontecimentos isolados, da trajetória de um único indivíduo, de modo a ampliar a compreensão sobre a história de outros, dos que o rodeiam.

\section{Resultados}

O levantamento bibliográfico realizado nas instituições de arte de Curitiba e nos periódicos CAPES detectou vasta quantidade de material jornalístico sobre Leonilson, porém escassa produção acadêmica sobre o mesmo.

A produção jornalística encontrada é composta por artigos de jornal e revista, publicados ao longo da vida e após o falecimento de Leonilson. Essas publicações estão pulverizadas em jornais e revistas especializados em arte e de interesse geral, porém nota-se maior concentração desses artigos no jornal Folha de São Paulo, para o qual Leonilson trabalhou como ilustrador na coluna de Barbara Gancia entre os anos de 1991 e 1993 (GANCIA e MESQUITA, 2006). 
Percebe-se que parte das publicações jornalísticas acessadas destaca a última fase da obra de Leonilson, quando ele descobriu ser soropositivo até falecer, trazendo para a discussão na época a relação obra-vida e a epidemia de AIDS (VIRIATO, 1993; GAMA, 1995; REIS, 1998b; DE ARAÚJO, 2011).

Dentre os artigos jornalísticos acessados, nota-se também certo contraste na caracterização feita sobre a obra de Leonilson. Sua obra é descrita como intimista, tendo caráter confessional (COELHO, 1996), ao passo que é também caracterizada como uma obra transgressora (PEDROSA, 1993). Segundo De Araújo (2011), só se pode afirmar que Leonilson aborda temas incômodos em sua obra, porém é de se negar que o artista, em seu isolamento, faça uma "arte do incômodo". Nesse sentido, a presente pesquisa foca-se na narrativa de Leonilson em relação à homossexualidade. Há evidencias acerca do caráter narrativo da obra de Leonilson, sendo este autobiográfico (PERIGO, 2014). Assim, face à atual conjuntura, que põe o debate sobre a homossexualidade em pauta, viu-se uma oportunidade e mesmo uma urgência em refletir sobre tal aspecto da obra do artista.

Chaimovich (1998) comenta sobre o recolhimento do artista como se ele trabalhasse em um diário, em caráter confidencial.

O mundo, do qual Leonilson se esquiva em seu trabalho, permanece como solo público das vivências do artista. Assim, a busca da autenticidade através da negação da experiência comum não é senão um modo comum de se estar no mundo. O isolamento pode criar uma ilusão de discurso para iniciados à primeira vista. 
Sob um outro aspecto, contudo, une o artista a preocupações fundamentalmente públicas (1998, sem página).

Observa-se que Leonilson, em seu trabalho altamente autobiográfico e intimista, como se fosse um diário aberto, trata de questões sociais, que dizem respeito a ordem social vigente da época. Por observarmos que a questão da homossexualidade é uma delas, escolhemos analisar a abordagem que ele faz dela em sua obra.

Leonilson, ao falar de si, fala sobre o mundo. Nesse sentido, pode-se compreender Cintrão (1997), quando ela afirma: "Leonilson é um artista do nosso tempo. Não apenas porque viveu nesta época, mas porque a viveu inserido em seus paradigmas" (1997, sem página). Segundo Cassundé (2011), Leonilson, a partir de suas experiências pessoais, por meio de sua poética, eleva questões particulares e as desdobra em temas universais para o encontro com o espectador, tornando-o cúmplice de suas questões.

Ainda sobre o levantamento de material acerca do artista nas instituições de arte de Curitiba, foram evidenciados dois aspectos. No Museu de Arte Contemporânea de Curitiba aconteceu a única exposição em Curitiba na qual o artista Leonilson participou. Trata-se da exposição coletiva AIDS - Consciência e Arte, sob a curadoria de Edilson Viriato, de 1993, após o falecimento do artista. Também foram identificadas três obras litográficas de Leonilson, pertencentes ao acervo do Museu da Gravura de Curitiba:Estigmas, curiositas, exvargos, 1989; Liberté, egalité, fraternité, 1989; Mesma saliva, mesmo veneno, 1991. 
Com base no levantamento bibliográfico realizado nos periódicos CAPES, observa-se que há pouca produção científica sobre o artista. Duas revistas, ARS e GAMA, contemplam toda a produção de artigos coletada nos periódicos CAPES. Entretanto, percebe-se que parte significativa das produções acadêmicas é recente e que Leonilson desperta interesse da comunidade científica internacional (HARRISON, 2003; AVELAR, 2014; GOIS, 2014).

Freitas (2008) analisa a obra de Leonilson dos últimos anos da década de 80. Segundo o autor (2008, 2010), nesse período as superfícies das obras se tornam mais monocromáticas, os materiais utilizados simplificam-se, há a redução de elementos no espaço pictórico e o que é pintado perde o horizonte de orientação.

A obra de Leonilson externa uma forte conexão entre a arte e a vida. No percurso dela observa-se uma desmaterialização do corpo e um encaminhamento para a transcendência. Nos últimos anos o bordado se sobressai, é um momento de intensa autorreflexão, evidenciada pela presença dos auto retratos. Aparece mais a questão da espiritualidade, do profano, da sexualidade, da morte (REIS, 1998a; LAGNADO, 2000; HARRISON, 2003; SALVETTI JR, 2010; CASSUNDÉ, 2011).

É tentador refletir sobre o uso da palavra na obra deste artista, como de fato fazem Beck (2004), Penharbel (2013), Avelar (2014) e Gois (2014). Penharbel (2013) e Gois (2014), baseados em Deleuze e Guattari, pensam o uso da palavra na obra de Leonilson como uma linguagem artística em devir, que se abre para outros modos de pensamento e criação. Leonilson é artista-escritor, no modo como lida com a linguagem 
verbal, tratando-a como elemento poético (BECK, 2004; AVELAR, 2014). Na obra de Leonilson há complementariedade nas linguagens verbal e visual, mas não no sentido lógico racional, como se houvesse uma legenda, uma narrativa para a imagem que se apresenta (BECK, 2004; CASSUNDÉ, 2009; PENHARBEL, 2013).

Leonilson se coloca contra a dicionarização da obra (PEDROSA in LAGNADO, 2000; BECK, 2004). "Um trabalho com palavras abre o leque para centenas de interpretações" (LEONILSON in LAGNADO, 2000, p.100). Beck (2004) comenta que Leonilson constrói léxico próprio, com uma semântica rica e uma sintaxe econômica. Leonilson não encerra significados de suas obras. Há verdades, no plural.

Em Leonilson, "verdade" antes de ser uma palavra que indica um caminho para a leitura, é significada ao longo da própria obra. "Verdade" indica um universo de possibilidades, cada uma delas apontada por um ou mais trabalhos. Assim, o que a obra de Leonilson em alguns momentos irá solicitar - principalmente naquelas obras em que o elemento plástico se reduz à palavra - é que o espectador desperte os significados adormecidos de suas próprias palavras. Que acione as suas imagens (BECK, 2004, p.114).

Em sua obra tão autobiográfica, Leonilson parece falar de nós, de uma ética da diversidade. A questão da homossexualidade passa a estar mais presente na obra de Leonilson entre as décadas de 80 e 90 (SALVETTI JUNIOR, 2010; FREITAS, 2010; DIAS in CASSUNDÉ, 2011; PERIGO, 2014). Sobre o contato que Leonilson teve com a estética gay, foi essencialmente com a literatura, lendo Cavafy e Oscar Wilde 
(LAGNADO, 2000). Além disso, o modelo de "homossexual" de Leonilson é aquele que mostra a hipocrisia dos bons costumes.

Mesmo assim, não se pode afirmar que Leonilson apresente uma grande questão sexual, esta, segundo Lagnado (in CYPRIANO, 2000a), foi sempre sublimada em seus trabalhos. Nesse sentido, o homoerotismo é um aspecto da obra de Leonilson, mas que não está hiante.

Seus trabalhos, que são marcados pelo impulso autobiográfico, uma tentativa de estabelecer um sentido em sua biografia, uma vivência particular de seu tempo, um configurar de mapas e anotações de viagens e em cujas obras há uma marca profunda da afirmação do sujeito e do desejo homossexual, adquirem uma radicalidade a partir da descoberta de sua soropositividade (REIS, 1998b).

As figuras desenhadas por Leonilson, como um signo, seja a cabeça, tronco ou corpo inteiro, em grande parte não são identificadas quanto ao gênero. Trata-se de figuras amorfas, há uma indefinição acerca do sexo. Quando há definição, configuram-se figuras masculinas. Segundo Lagnado (2000), a obra de Leonilson também contém uma potência homoerótica, na utilização de elementos fálicos.

Há parte significativa de obras de Leonilson dedicadas aos seus amores, paixões impossíveis, como: "Jogos perigosos, 1990"; "Sou seu homem, 1992" e "Longo caminho de um rapaz apaixonado, sem data". 


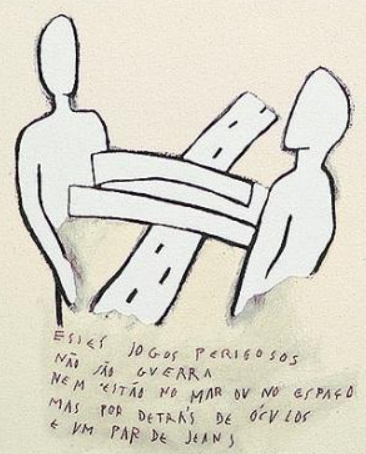

Figura 1: Jogos perigosos, 1990. Desenho sobre papel.

Fonte: Espaço humus. Disponível em: <http://espacohumus.com/leonilson/>.

Já nas palavras bordadas e desenhadas, observam-se dois processos. Por um lado, Leonilson faz referência em algumas obras à figuras masculinas, como é o caso de "Rapaz dividido, 1991". Em outro sentido, algumas obras de Leonilson, como "O ilha, 1990", "Los delicias, 1993" e "O Penélope, 1993", há a silepse de gênero, fusão do masculino e feminino em um mesmo objeto. Leonilson utiliza pronomes femininos para substantivos masculinos.

Segundo Lagnado (2000), trata-se da dimensão poética de Leonilson. Para a autora (2000) e Cassundé (2009), Leonilson não segue regras de sintaxe e gênero. Beck (2004) vislumbra outra questão. Para a autora (2004), nesse processo, Leonilson transforma um substantivo comum feminino em nome próprio, ao colocá-lo um artigo masculino.

É possível pensar sobre a questão da verdade nessas obras. A indefinição das figuras e em algumas o jogo da ambiguidade fornecem 
indícios de uma compreensão sobre gênero na obra de Leonilson que gira em torno de verdades, da diversidade. Pode-se entender que Leonilson rompe com a binaridade entre masculino e feminino, o que vai contra a heteronormatividade e dialoga com as discussões de gênero.

Segundo Harrison (2003), Salvetti Jr (2010) e Cassundé (2011), na década de 80, a AIDS estava atrelada a um discurso sobre a promiscuidade e ao estigma de uma 'praga gay', com implicações morais e sociais. O próprio Leonilson observa esta situação:

Ser gay hoje em dia é a mesma coisa que ser judeu na Segunda Guerra Mundial. O próximo pode ser você, a praga tá aí pronta pra te pegar. Essa é a única razão pela qual eu não me jogo nas coisas. Mas isso também faz a consciência da gente aumentar, faz a gente ficar mais forte, faz eu querer ser um homem forte (Trecho do livro Frescoe Ulisses, organizado por Ricardo F. Henrique in CYPRIANO, 2000a, sem página e documentário Com o oceano inteiro para nadar, 1997).

Pois é nesse contexto, que o artista Leonilson, em sua postura de constante curiosidade sobre o mundo e ao mesmo tempo reflexão de si, vivia e produzia sua obra. Esse quadro situacional não está tão modificado assim: "Ainda hoje, cristãos menos iluminados atribuem o flagelo da Aids ao castigo divino contra a revolução sexual e o movimento gay"(MOTT, 2006, p.509).

A obra de Leonilson estaria no rumo de uma estética gay? Segundo Leonilson (in LAGNADO, 2000), não.

Uma das características dos meus trabalhos é a 
ambiguidade. A gente falou de sexualidade na semana passada. Eu dizia que meus trabalhos eram meio gays assim, mas não é isso. Acho que eles são ambíguos mesmo (...) Os bordados revelam minha ambiguidade na minha relação como homem (LEONILSON in LAGNADO, 2000, p.116).

E mais: "Os trabalhos são todos ambíguos. Eles não entregam uma verdade diretamente, mas mostram uma visão aberta" (LEONILSON in LAGNADO, 2000, p.20) Como Freitas (2010) e Perigo (2014) observam, Leonilson explora o tema da verdade, mostrando interesse na reflexão sobre o radicalismo, intolerância e preconceito. Isso, segundo Perigo (2014) e Lagnado (sem ano) o caracteriza como um ativista cultural. Mas de que ativismo se trata?

"Eu não extravaso com violência, nem com o uso do poder, mas acho que as coisinhas calminhas cutucam tanto quanto um tiro na testa". (LEONILSON in LAGNADO, 2000, p.88).

Inconformado e ao mesmo tempo solitário em sua obra (FREITAS, 2010), Leonilson sutilmente aborda a questão da homossexualidade. Não se trata de um ativismo político, panfletário (LAGNADO, 2000). "Nem a mais remota sombra de ativismo gay, ou qualquer outro ativismo. Nenhuma reivindicação ou grito- ainda que alguma revolta e protesto" (DE ARAÚJO, 2011, sem página).

$\mathrm{O}$ ativismo em Leonilson parece estar justamente no questionamento das verdades, na possibilidade de pluralidade de pensamento e não num enaltecimento de uma orientação sexual. Nesse sentido, Aguilar afirma: "A valorização da ideologia gay pertence mais 
ao sem-sentido da hora que a uma instância essencial da obra"(1996, sem página). Leonilson, em entrevista à Lagnado (2000), faz a afirmação que não deixa mais dúvidas: "Acho que mostrar que gay também ama (...) Mas não que eu seja um defensor que sai com uma bandeira (...)"(p.103).

A obra a seguir é composta por um tecido voile bordado com linha preta. Nela, vê-se escrito: "Para quem comprou a verdade, os louros, o cetro, o tombo". O bordado ocupa a área de cima e de baixo do voile, deixando ao meio um grande espaço em branco. Esta obra sugere a existência de alguém que comprou a verdade. Fala-se na necessidade de discutir as possibilidades de verdades. Nesse sentido, a obra, se utilizando da temporalidade, alerta: verdades enrijecidas têm como fim, o tombo.

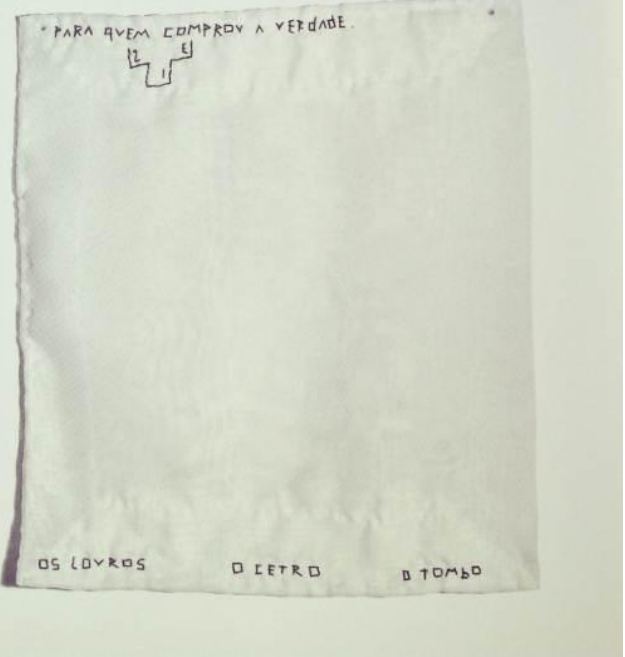

Figura 2: Leonilson. Para quem comprou a verdade. 1991. Bordado sobre voile. 39x $35 \mathrm{~cm}$. Coleção Luciana Brito e Fábio Cimino. Fonte: PERIGO, Katiucya. Leonilson e a narrativa de si. Ciclos, 2 (3), p.87-102, 2014. 
As palavras de Leonilson compactuam com a postura que ele adota como artista. Leonilsonse entende como um curioso, observador do mundo. Em sua última entrevista à Lagnado (2000), afirma:

Se você quiser uma descrição de mim, eu acho que eu sou um curioso. E sou ambíguo, completamente. Os trabalhos são todos ambíguos. Eles não entregam uma verdade diretamente, mas mostram uma visão aberta. Eu nunca me conformei com um lado único das coisas (...) Sou mais um curioso do que um artista (p.128). Leonilson fala sobre a aceitação da homossexualidade pela sociedade:

Sinceridade. Não existe sinceridade nenhuma. O problema é que as pessoas são mascaradas mesmo. Esse negócio de gay, de lésbica é temido como as pessoas temem o diabo (...) Os pais têm mais medo que o filho seja gay do que de que ele seja bandido. Gay, para a sociedade na qual a gente vive, é o último degrau (LEONILSON in LAGNADO, 2000, p.104).

Em trecho publicado pelo jornal Folha de São Paulo, do livro Frescoe Ulisses, produzido a partir das gravações de voz deixadas por Leonilson, o artista aborda de modo mais aberto sobre a sexualidade. $\mathrm{O}$ livro não foi publicado, por veto de seus familiares (CYPRIANO, 2000b).

Eu nasci em Fortaleza e eu moro em São Paulo mas eu não sou paulistano, às vezes acho que não pertenço a lugar nenhum. Eu ando aqui nas ruas e eu não sou um hispano, por exemplo. Eu não sou preto, eu não sou armênio, eu sou brasileiro... Eu não sou uma rainha, uma queen, eu sou um homem... eu tenho certeza da minha masculinidade... eu gosto de rapazes (Trecho do livro Frescoe Ulisses, organizado por Ricardo F. Henrique in CYPRIANO, 2000a). 
Deve-se lembrar que esta frase de Leonilson é a voz do artista em sua obra. Em relação a questões de vida-obra que Leonilson possa suscitar, Lagnado (2000) e Gois (2014) advertem que é problemático identificar a obra pela orientação sexual do artista e vice-versa. Isso seria reducionista, modelo de explicação da obra que fecha os sentidos da mesma numa explicação biográfica.

Nesse trecho, Leonilson é poético e, em relação a sua substância, parece tratar da questão da sexualidade, na possibilidade de diferentes modos de ser, da dificuldade de se enquadrar em categorias, supostas verdades. Aqui novamente a ambiguidade se faz presente e parece chamar para a necessidade de compreensão da diversidade, o que coaduna com os interesses do movimento LGBT na atualidade.

Segundo Nucci e Russo (2008) há uma concepção de homossexualidade, criada no século XIX, na qual o homossexual é visto como possuidor de uma alma feminina em um corpo masculino, chamase teoria do terceiro sexo. Ao analisar o modo como Leonilson se refere à homossexualidade, evidencia-se o oposto. Leonilson é a queen, os hispanos, os armênios. Leonilson novamente apresenta possibilidades e não uma verdade a se impor. Nesta fala, Leonilson, obra e artista, se confundem. Leonilson afirma sua identidade de gênero: é homossexual, não é dragqueen, não é transexual, é homem que gosta de homem. Essa é a sua verdade. 


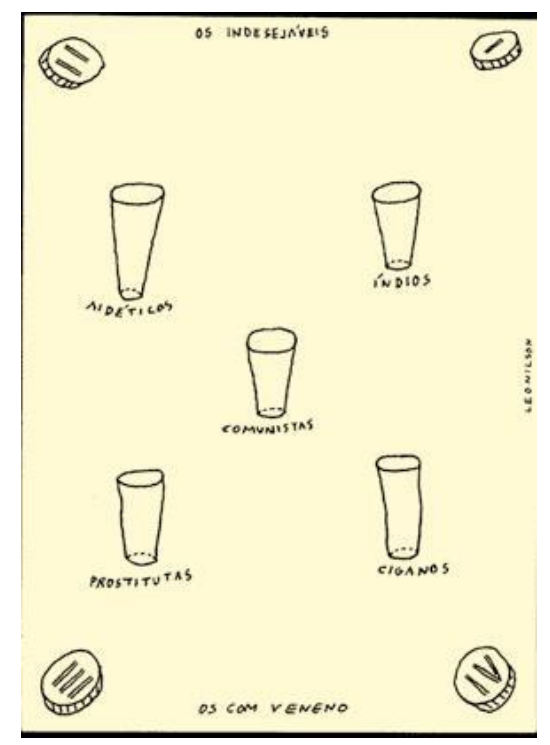

Figura 3: Leonilson. Sem título. 1991. Desenho sobre papel, publicado em Folha de São Paulo, Caderno São Paulo, p.2, 4 set. 1991. Fonte: GANCIA, Barbara;

MESQUITA, Ivo. Leonilson: Use, é lindo, eu garanto. 2.ed São Paulo: Cosacnaify, 2006.

Na obra "Os indesejáveis" (sem nome, 1991, para o artigo "Os chatos unidos foram enfim vencidos" in GANCIA e MESQUITA, 2006, p.66), Leonilson também fala dos outsiders e é um deles. Trata-se de uma ilustração para artigo de Barbara Gancia. Deve-se lembrar que as ilustrações foram realizadas em função do artigo que acompanhavam. Mesmo assim, é possível pensar na ampliação de significados da obra, tendo em vista também sua qualidade estética.

É um desenho sobre papel, no qual três elementos diferentes ocupam todo o espaço do papel de forma ordenada. Em cima, na parte central, escreve-se "Os indesejáveis" e no canto inferior "Os com veneno". Como em outros desenhos de Leonilson, há o signo da moeda 
nos quatro cantos do papel (I, II, III, IV). No centro do papel, há cinco copos (um centralizado e os outros quatro divididos em cima e embaixo) Abaixo de cada um dos copos inscreve-se um tipo indesejável: Aidéticos, Índios, Comunistas, Prostitutas, Ciganos.

Nesta obra, a palavra e o desenho se transformam em uma linguagem só, enquanto imagem e semântica. Os copos separam os "tipos" marginalizados, como em guetos. O homossexual não está incluso na lista, mas mesmo assim, a obra ecoa até ele. Esta ilustração, de modo conciso, mas com o traço pessoal de Leonilson, não levanta bandeira de grupo político, mas de forma austera, expõe o que todos fingem não ver, os grupos minoritários.

Percebe-se que a questão da ambiguidade, presente na obra de Leonilson, quando este discute sobre a sexualidade em suas obras, aponta para uma ética da sexualidade. Ética, entendida como "estudo dos juízos de apreciação referentes à conduta humana suscetível de qualificação do ponto de vista do bem e do mal" (FERREIRA, 1999, p.848).

"Tentando desconstruir discursos conservadores, alguns pensadores contemporâneos, pretendem esvaziar sentidos moralistas da doença (...). Mais contemporaneamente, as artes plásticas são uma arena importante para a discussão da Aids" (REIS, 1998b, sem página). O pesquisador tece este comentário de modo a introduzir a obra de Leonilson em sua última fase. Torna-se possível pensar em ampliar esse significado para a questão da homossexualidade. Leonilson, em seu trabalho, que se apresenta com elementos ambíguos, questiona os sentidos moralistas da sexualidade. 


\section{Considerações Finais}

No ponto que chegamos, é necessário questionar: 'Pode-se dizer que há um corpo temático envolvendo a homossexualidade na obra de Leonilson?' A homossexualidade, nas obras dedicadas aos rapazes, nos amores impossíveis se faz presente, sem dúvida. Mas isso acontece também porque é a partir de uma narrativa de si que Leonilson constrói sua obra.

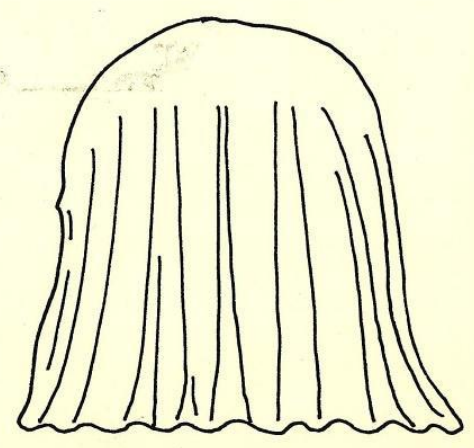

QUEM SOU?

O quE FAÇO?

PRA' ONDE VOU?

Figura 4: Leonilson. Sem título. 1991, desenho sobre papel. Publicado em Folha de São Paulo, Caderno São Paulo, p.2, 9 out. 1991. Fonte: GANCIA, Barbara; MESQUITA, Ivo. Leonilson: Use, é lindo, eu garanto. 2.ed São Paulo: Cosacnaify, 2006. 
De forma mais ampla, tendo em vista o jogo de ambiguidade em suas obras, Leonilson nos possibilita pensar a diversidade de gênero. A ilustração "Elefante com paninho em cima", feita para a Folha de São Paulo (in GANCIA e MESQUITA, 2006, p.76), é um desenho com uma figura central não identificada, pois está coberta com um pano, em cima dela diz: "Elefante branco com paninho em cima". Ao topo da ilustração estão polarizados os escritos "Eu amo" e "Eu odeio". Na outra extremidade do papel, as perguntas existenciais: "Quem sou?", "O que faço?", "Pra onde vou?".

Nessa obra, em que a ambiguidade também se apresenta em relação aos sentimentos e aos significados desse elefante branco, há um tom de ironia. Ela não aborda a temática da sexualidade. Mesmo assim, tratando de verdades de Leonilson, ela permite a ampliação de seus significados para outras searas. O que não se quer ver, não se vê, não se discute. Elefante branco com um paninho em cima. E é a partir disso que se formam os discursos de amor e ódio. Pensar gênero demanda que a sociedade pense em verdades, possibilidades de existência. A obra de Leonilson tem uma atualidade inegável.

Leonilson foi um artista em consonância com seu tempo. Com a habilidade em se trabalhar a ambiguidade, ele traz à tona a discussão da pluralidade de gênero, que se faz tão necessário debater na atualidade. Nesse sentido, observa-se então que Leonilson nos fala de uma 'não questão da homossexualidade', esta como uma das formas de ser do humano. 
Este foi um breve estudo, que vislumbra a possibilidade de se refletir gênero a partir de Leonilson. Contudo, não se quer aqui esgotar o assunto, pois se constata que tal aspecto da obra desse artista merece ser mais explorada, tendo em vista também a escassez de pesquisas que serviriam de referência para a arte brasileira contemporânea.

\section{Referências}

AGUILAR, Nelson. As verdades de Leonilson. Jornal Folha de São Paulo, São Paulo, 08 mar. 1996.

AVELAR, Daniela Cavalin. Leonilson e as palavras. GAMA, 4, p.52 57, 2014.

BACELAR, Carina; CARVALHO, Cleide. Bancada evangélica cresce 14\% e deve prejudicar causas LGBT. Jornal O Globo. 08, out. 2014. Disponível em: http://oglobo.globo.com/brasil/bancada-evangelicacresce-14-deve-prejudicar-causas-lgbt-14178049.

BECK, Ana Lúcia. Leonilson e a inserção de palavras nas artes visuais. 180 p. Dissertação - Universidade Federal do Rio Grande do Sul, 2004.

Casamento gay: a pauta é diferente nos EUA e no Brasil. Revista Veja, 27 mar. 2013. Disponível em: http://veja.abril.com.br/noticia/mundo/casamento-gay-a-pauta-ediferente-nos-eua-e-no-brasil.

CASSUNDÉ, Carlos Eduardo Bitu. Leonilson e a catalogação da vida. Jornal Diário do Nordeste, 08 fev. 2009.

CASSUNDÉ, Carlos Eduardo Bitu. Leonilson: a natureza do sentir. 165 p. Dissertação- Universidade de Minas Gerais. Escola de Belas artes. Mestrado em Artes, 2011. 
CINTRAO, Rejane. Leonilson: O solitário inconformado. Museu de Arte Contemporânea, São Paulo, 1997. (Folheto).

COELHO, Marcelo. Obra de Leonilson busca comunicação ideal. Jornal Folha de São Paulo, São Paulo, 05 jan. 1996.

Com o oceano inteiro para nadar. Documentário. Direção de Karen Harley, 1997.

CYPRIANO, Fabio. Memória silenciada. Jornal Folha de São Paulo, São Paulo, 18 out. 2000a.

CYPRIANO, Fabio. Família suspende biografia de Leonilson. Jornal Folha de São Paulo, São Paulo, 27 nov. 2000b.

DE ARAÚJO, Olívio Tavares. Amor, doença, morte: a vida na obra de Leonilson. Jornal O Estado de São Paulo, São Paulo, 28 abr. 2011.

DIÓGENES, Juliana. Evangélicos retomam debate da 'cura gay'. Jornal O Estado de São Paulo. São Paulo, 16 mai. 2015. Disponível em: http://brasil.estadao.com.br/noticias/geral,evangelicos-retomam-debateda-cura-gay, 1688867

FERREIRA, Aurélio Buarque de Holanda. Novo Aurélio Século XXI: o dicionário da língua portuguesa. 3 ed. Rio de Janeiro: Nova Fronteira, 1999.

FREITAS, Carlos Eduardo Riccioppo. Leonilson - uma questão de escala. ARS (São Paulo), São Paulo, v. 6, n. 12, p. 129-140, dez. 2008.

FREITAS, Carlos Eduardo Riccioppo. Leonilson, 1980-1990. Dissertação- Universidade de São Paulo, 2010.

GANCIA, Barbara; MESQUITA, Ivo. Leonilson: Use, é lindo, eu garanto. 2.ed São Paulo: Cosacnaify, 2006.

GOIS, Wilma Farias. O pescador de palavras: Leonilson e o sensível na linguagem. GAMA, 4, p.58-65, 2014. 
HAUBERT, Mariana. Deputados evangélicos protestam contra parada gay e rezam no plenário. Jornal Folha UOL, Brasília, 10 jun. 2015. Disponível em: http://www1.folha.uol.com.br/poder/2015/06/1640504bancada-evangelica-faz-manifestacao-contra-parada-gay-e-reza-painosso-no-plenario-da-camara.shtml.

HARRISON, Marguerite Itamar. Leonilson'slossisourgain: transformingstitchedwordsandimagesofdeteriorarionintoredemption.

Revista de crítica literaria y de cultura, 10, 2003.

http://espacohumus.com/leonilson/> Acessado em: 5 jun. 2015.

LAGNADO, Lisette. Para quem não comprou a verdade. Sem ano.

LAGNADO, Lisette. São tantas as verdades: Leonilson. 2ed. São Paulo: DBS, 2000.

MOTT, Luis. Homo-afetividade e direitos humanos. Rev. Estud. Fem., Florianópolis, v. 14, n. 2, p. 509-521, 2006.

NATIVIDADE, Marcelo. Homossexualidade, gênero e cura em perspectivas pastorais evangélicas. Rev. bras. Ci. Soc., São Paulo, v. 21, n. 61, p. 115-132, 2006.

NUCCI, Marina Fisher; RUSSO, Jane Araújo. O terceiro sexo revisitado: a homossexualidade no Archivesof Sexual Behavior. Physis, Rio de Janeiro, v. 19, n. 1, p. 127-147, 2009.

OLIVA, Fernando. Leonilson ganha o MoMA. Jornal Folha de São Paulo, São Paulo, 02 jun. 1999.

PEDROSA, Joao. Ave, Leonilson. Revista Casa Vogue. Ano 17, n.2, 1993.

PENHARBEL, Silvia Flores. Inscrições perfomáticas no campo visual das obras de Leonilson e Basquiat. 110p. Dissertação- Universidade Estadual de Londrina, 2013. 
PERIGO, Katiucya. Leonilson e a narrativa de si. Ciclos, 2 (3), p.87-102, 2014.

Projeto Leonilson. Disponível em: http://www.projetoleonilson.com.br> Acessado em: 10/02/2015

REIS, Paulo Roberto de Oliveira. A construção do desenho: sujeito, temporalidade e cartografias em Leonilson. Dissertação- Pontifícia Universidade Católica do Rio de Janeiro, 1998a.

REIS, Paulo Roberto de Oliveira. Imagens Soropositivas. Jornal Gazeta do Povo, Curitiba, 01 dez. 1998b.

REVEL, Jacques. Micro-história, macro-história: o que as variações de escala ajudam a pensar em um mundo globalizado. Rev. Bras. Educ., Rio de Janeiro, v. 15, n. 45, p. 434-444, 2010.

Rio recebe objetos e Angelo de Aquino e mostra de Leonilson. Jornal Folha de São Paulo, São Paulo, 25 out. 1996.

SALVETTI JUNIOR, Paulo Roberto. 221p. Dissertação- Percursos para a construção do corpo em trânsito. Universidade Federal do Rio Grande do Sul, 2010.

VIRIATO, Edilson. AIDS: Consciência e arte. Museu de Arte Contemporânea, Curitiba, 1993. (Folheto). 